\title{
Assessment of the views of intensive care nurses about the effect of patient visiting hours on patients and nursing care
}

\author{
H Sütçü Çiçek ${ }^{*}$, N Cambaztepe ${ }^{2}$, B Kllı̧̧ \\ From ESICM LIVES 2015 \\ Berlin, Germany. 3-7 October 2015
}

\section{Introduction}

Policies of visiting in intensive care units effect both patients care and nursing care.

\section{Objective}

This study aims to assess views of intensive care nurses about the effect of patient visiting hours on patients and nursing care.

\section{Methods}

A data gathering questionnaire consisting of 20 questions has been used in this descriptive research. Among the nurses working in the departments of medical and surgical intensive care units of a teaching and research hospital, the ones who have given their consents has been included in the study.

\section{Results}

120 nurses who are working at medical and surgical intensive care units have been included in the study. Mean age for the nurses is $29 \pm 5.7$ and $82.5 \%$ of them have bachelor's degrees. All the nurses participating in the study stated that patient visiting hours are not completely flexible and individual, age and time constrictions do exist. $88.3 \%$ of the nurses stated that they take isolation precautions for the visitors when the visitors are in the intensive care unit. $92.3 \%$ of the medical intensive care nurses and $52 \%$ of the surgical intensive care nurses see the patient visiting hours as a source of stress. Furthermore, $52.3 \%$ of the nurses with 1 to 5 years of ICU work time, $61 \%$ of the nurses with 6 to 10 years of ICU work time, $61.4 \%$ of the nurses with

${ }^{1}$ Gulhane Military Medical Academy, School of Nursing, Etlik, Turkey

Full list of author information is available at the end of the article
11 to 15 years of ICU work time and $87.5 \%$ of the nurses with more than 15 years of ICU work time states that patient visiting hours increase their work load. Statistically this is significant. $57 \%$ of the nurses consider the visiting hours as having a negative impact on the nursing care given to the patients. About the appropriate visiting hours, $10 \%$ of the nurses state that as long as full isolation precautions are applied there should be no restrictions, $89.2 \%$ of the nurses state that time, individual and age restrictions should be applied, and $0.8 \%$ of the nurses state that it should be severely restricted and a rigid observation of rules should be applied.

\section{Conclusions}

Although, intensive care nurses state that, patient visiting hours are a source of stress for them, increase their workload and negatively affect the quality of the nursing care most of them, they suggested that visits should be continued with brief interviews.

\section{Grant Acknowledgment}

This research received no specific grant from any funding agency in the public, commercial, or not-for-profit sectors.

\section{Authors' details}

'Gulhane Military Medical Academy, School of Nursing, Etlik, Turkey.

${ }^{2}$ Gulhane Military Medical Academy, Department of Norology, Etlik, Turkey.

Published: 1 October 2015

\section{References}

1. Cappellini E, Bambi S, Lucchini A, Milanesio E: Open intensive care units: a global challenge for patients, relatives, and critical care teams. Dimens Crit Care Nurs 2014, 33(4):181-93, Jul-Aug. (c) 2015 Sütçü Çiçek et al.; This is an Open Access article distributed under the terms of the Creative Commons Attribution License (http://creativecommons.org/licenses/by/4.0), which permits unrestricted use, distribution, and reproduction in any medium, provided the original work is properly cited. 
2. Hart A, Hardin SR, Townsend AP, Ramsey S, Mahrle-Henson A: Critical care visitation: nurse and family preference. Dimens Crit Care Nurs 2013, 32(6):289-99, Nov-Dec.

3. Athanasiou A, Papathanassoglou ED, Patiraki E, McCarthy MS,

Giannakopoulou M: Family visitation in greek intensive care units: nurses' perspective. Am J Crit Care 2014, 23(4):326-33, Jul;

doi:10.1186/2197-425X-3-S1-A922

Cite this article as: Sütçü Çiçek et al:: Assessment of the views of intensive care nurses about the effect of patient visiting hours on patients and nursing care. Intensive Care Medicine Experimental 20153 (Suppl 1):A922.

\section{Submit your manuscript to a SpringerOpen ${ }^{\circ}$ journal and benefit from:}

- Convenient online submission

- Rigorous peer review

- Immediate publication on acceptance

- Open access: articles freely available online

- High visibility within the field

- Retaining the copyright to your article 